\title{
DAYA TERIMA, KADAR PROTEIN DAN ZAT BESI COOKIES SUBTITUSI TEPUNG DAUN KELOR DAN TEPUNG KECAMBAH KEDELAI
}

\author{
Acceptability, Protein, and Iron Level of Moringa Leaf Flour and \\ Germinated Soy Flour
}

\author{
Yulia Kurnia Sari ${ }^{1}$, Annis Catur Adi ${ }^{2}$ \\ ${ }^{1}$ Program Studi S1 Kesehatan Masyarakat, Fakultas Kesehatan Masyarakat, Universitas Airlangga, Surabaya \\ ${ }^{2}$ Departemen Gizi Kesehatan, Fakultas Kesehatan Masyarakat, Universitas Airlangga, Surabaya \\ Email: sari.yuliakurnia@gmail.com
}

\begin{abstract}
ABSTRAK
Daun kelor dan kecambah kedelai merupakan tanaman lokal Indonesia yang memiliki kandungan gizi cukup tinggi namun masih kurang dalam pemanfaatannya. Daun kelor kaya akan zat besi dan kecambah kedelai sebagai sumber protein nabati dapat menjadi bahan makanan alternatif yang dapat disubstitusikan ke dalam cookies sebagai PMT pemulihan balita KEP fase rehabilitasi. Tujuan dari penelitian ini adalah untuk menganalisis pengaruh substitusi tepung daun kelor dan tepung kecambah kedelai terhadap daya terima, kadar protein, dan zat besi cookies. Jenis penelitian adalah eksperimental murni dengan desain rancangan acak lengkap (RAL). Panelis tidak terlatih adalah 30 ibu balita usia 1-3 tahun. Analisis statistik perbedaan daya terima yang digunakan adalah uji Kruskal Wallis $(\alpha \leq 0,05)$. Hasil uji daya terima menunjukkan bahwa formula yang paling disukai adalah cookies F1 (tepung terigu $150 \mathrm{~g}$, tepung daun kelor $10 \mathrm{~g}$, dan tepung kecambah kedelai $40 \mathrm{~g}$ ) memiliki modus 3 (suka) dan kadar protein $9 \mathrm{~g}$ serta kadar zat besi 3,21 mg per takar saji (100 g cookies). Hasil analisis statistik menunjukkan adanya perbedaan daya terima pada karakteristik warna $(\mathrm{p}=0,000)$, aroma $(\mathrm{p}=0,000)$, tekstur $(\mathrm{p}=0,000)$ dan rasa $(\mathrm{p}=0,000)$.
\end{abstract}

Kata Kunci: daya terima, protein, zat besi

\section{ABSTRACT}

Moringa leaves and soybean sprouts are local plants in Indonesia that contains high nutrient but it utilization are still low. Moringa leaves are rich in iron and soybean sprouts are source of vegetable protein which can be used as an alternative food material to substitute cookies for supplementary feeding in the rehabilitation phase of protein energy malnutrition management. The purpose of this study was to analyze the effect of substitution of Moringa leaf powder and soybean sprouts flour against acceptance, the protein and iron content of cookies. Type of research was true experimental with completely randomized design. Thirty mother of children aged 1-3 years were used as untrained panelists. Product acceptance was tested using statistical analysis Kruskal Wallis $(\alpha \leq 0.05)$. The result of product acceptance test showed that the most preferred cookies was F1 (150 g wheat flour, flour $10 \mathrm{~g}$ Moringa leaves and $40 \mathrm{~g}$ soybean sprouts flour), which had modus 3 (like) and also protein content is $9 \mathrm{~g}$ and iron content is 3,21 mg per serving size (100 g cookies). Statistical analysis showed significant difference in colour $(p=0.000)$, aroma $(p=0.000)$, texture $(p=0.000)$ and flavor $(p=0.000)$ characteristics.

Keywords: acceptance, protein, iron

\section{PENDAHULUAN}

Balita merupakan salah satu kelompok usia yang rentan terhadap masalah gizi. Salah satu masalah gizi yang terjadi pada balita yaitu Kurang Energi Protein (KEP). KEP memiliki dampak berkepanjangan bila menyerang balita. Selain menghambat pertumbuhan dan perkembangan, balita KEP akan menjadi sumber daya manusia yang kurang berkualitas bila KEP tidak ditangani dengan tepat.

Penanganan pada balita KEP dapat dilakukan dengan memberikan terapi diet berupa PMT pemulihan saat memasuki fase rehabilitasi (Kemenkes, 2011). Kegiatan pemberian PMT 
pemulihan pada balita KEP telah menjadi kegiatan tata laksana gizi yang tertera dalam Peraturan Menteri Kesehatan RI Nomor 1 Tahun 2014.

Bentuk makanan yang dapat dijadikan PMT pemulihan balita KEP yaitu cookies karena sebagian besar balita gemar mengonsumsi cookies. Salah satu cara untuk menjadikan cookies sebagai makanan tinggi protein dan zat besi adalah dengan substitusi dengan tepung daun kelor dan tepung kecambah kedelai. Daun kelor merupakan bahan makanan dengan nilai gizi tinggi terutama zat besi. Zat besi dalam 100 gram daun kelor yaitu $7 \mathrm{mg}$, apabila ditepungkan menjadi $28,2 \mathrm{mg}$. Kadar zat besi daun kelor yang tinggi diharapkan dapat mengatasi masalah anemia pada balita KEP. Menurut WHO (2014), anemia pada balita dapat menghambat perkembangan kognitif, pertumbuhan fisik, dan balita mudah terserang infeksi. Gangguan ini tidak dapat diperbaiki dengan terapi zat besi berikutnya.

Kecambah kedelai merupakan salah satu bahan makanan sumber protein nabati. Kadar protein pada kecambah kedelai sekitar 9 gram/100 gram bahan, sedangkan saat ditepungkan, kadar proteinnya menjadi 37,5 gram/100 gram bahan. Kecambah kedelai memiliki protein yang lebih mudah dicerna dari pada kedelai karena ikatan protein kedelai diubah menjadi bentuk yang lebih aktif. Kedelai juga memiliki zat anti gizi yaitu asam fitat dan tripsin inhibitor, namun aktivitas zat anti gizi ini dapat dikurangi dengan adanya perkecambahan (Nwamaka, 2008). Kecambah kedelai sangat sesuai bila diberikan kepada balita KEP karena selain memiliki kadar protein yang tinggi, kecambah kedelai mengandung isoflavon.

Isoflavon merupakan antioksidan yang sangat kuat sehingga dapat meningkatkan imunitas balita KEP yang pada dasarnya rentan terserang infeksi (Nursanyoto, 2012). Tujuan dari penelitian ini adalah untuk mengetahui pengaruh substitusi tepung daun kelor dan tepung kecambah kedelai terhadap daya terima, kadar protein, dan kadar zat besi cookies.

\section{METODE}

Penelitian yang dilakukan saat tahap pengembangan formula adalah penelitian eksperimental murni dengan menggunakan desain penelitian rancangan acak lengkap (RAL). Penelitian ini dilakukan pada bulan OktoberNopember 2016. Pembuatan cookies dilakukan di Laboratorium Gizi Fakultas Kesehatan Masyarakat Universitas Airlangga Surabaya. Uji organoleptik dilakukan di Desa Bulak Kali Tinjang Baru Kecamatan Bulak Kota Surabaya dan uji kadar protein di Laboratorium Badan Penelitian dan Konsultasi Industri (BPKI) Surabaya.

Pembuatan formula cookies disesuaikan dengan standar PMT balita KEP fase rehabilitasi yaitu 1/3 AKG usia 1-3 tahun. Sampel penelitian adalah cookies substitusi tepung daun kelor dan tepung kecambah kedelai dengan formula cookies yang telah ditentukan. Ukuran sampel yang disajikan pada panelis adalah $25 \mathrm{~g}$ cookies untuk setiap formula cookies. Sampel diambil dengan cara randomisasi. Panelis menilai sampel yang disajikan dengan menggunakan angket uji kesukaan meliputi warna, aroma, tekstur dan rasa dengan 4 skala kesukaan yaitu sangat tidak suka, tidak suka, suka, dan sangat suka. Panelis yang digunakan pada penelitian ini adalah ibu balita usia 1-3 tahun di Desa Bulak Kali Tinjang Baru Kecamatan Bulak Kota Surabaya sebanyak 30 orang. Ibu balita dipilih sebagai panelis karena penentuan makanan balita masih tergantung pada ibunya dan balita usia 1-3 tahun belum mampu melakukan uji organoleptik. Bahan yang digunakan dalam pembuatan cookies tepung daun kelor dan tepung kecambah kedelai adalah tepung terigu, tepung daun kelor, tepung kecambah kedelai, tepung maizena, gula tepung, mentega tawar, margarin, butter, kuning telur, putih telur, tepung susu, vanili, garam, dan baking powder.

Proses pembuatan cookies dimulai dengan mencampurkan semua bahan, lalu mencetak adonan, dan memanggangnya selama 30 menit pada suhu $130^{\circ} \mathrm{C}$. Formulasi cookies tepung daun kelor dan tepung kecambah kedelai pada penelitian ini disajikan pada Tabel 1.

Penilaian yang dilakukan adalah menguji daya terima terhadap karakteristik warna, aroma, tekstur dan rasa yang didapatkan dari penilaian panelis menggunakan angket uji kesukaan, perhitungan kadar protein dan zat besi berdasarkan TKPI (Tabel Komposisi Pangan Indonesia) 2009 dan 
Tabel 1. Formula Cookies Tepung Daun Kelor dan Tepung Kecambah Kedelai

\begin{tabular}{lcccc}
\hline \multirow{2}{*}{ Komposisi } & \multicolumn{3}{c}{ Formula (g) } \\
\cline { 2 - 5 } & F0 & F2 & F3 & F4 \\
\hline Tepung Terigu & 200 & 150 & 140 & 130 \\
Tepung Daun Kelor & 0 & 10 & 15 & 20 \\
Tepung Kecambah Kedelai & 0 & 40 & 45 & 50 \\
Tepung Maizena & 30 & 30 & 30 & 30 \\
Gula Tepung & 100 & 100 & 100 & 100 \\
Mentega Tawar & 80 & 80 & 80 & 80 \\
Margarin & 30 & 30 & 30 & 30 \\
Butter & 10 & 10 & 10 & 10 \\
Kuning Telur & 60 & 60 & 60 & 60 \\
Putih Telur & 30 & 30 & 30 & 30 \\
Tepung Susu & 20 & 20 & 20 & 20 \\
\hline
\end{tabular}

uji laboratorium kimia dengan metode Kjeldahl dan Atomic Absorbent Spectrofotometri (AAS). Teknik analisis yang digunakan secara deskriptif menggunakan uji statistik Kruskal Wallis $\alpha \leq 0,05$.

Penelitian ini melibatkan subyek manusia sebagai panelis dan telah mendapatkan persetujuan dari Komisi Etik Penelitian Kesehatan No: 530KEPK Fakultas Kesehatan Masyarakat Universitas Airlangga Surabaya.

\section{HASIL DAN PEMBAHASAN}

Daya terima merupakan gambaran seseorang menyukai atau tidak menyukai suatu produk makanan yang dinilai dengan cara melakukan uji organoleptik dengan menggunakan panca indera. Warna makanan sangat mempengaruhi seseorang untuk mau menerima produk makanan, oleh karena itu warna menjadi hal yang penting dalam pembuatan produk (Harisina, 2016).

Hasil uji daya terima terhadap warna cookies ditampilkan pada Tabel 2. Warna yang paling tidak disukai oleh panelis yaitu formula F1 $(23,3 \%)$, sedangkan formula F2 memiliki persentase terendah untuk kategori tidak disukai (10\%) bila dibandingkan dengan formula modifikasi yang lain. Hasil uji Kruskal Wallis menunjukkan bahwa terdapat pengaruh yang signifikan substitusi tepung daun kelor dan tepung kecambah kedelai terhadap warna cookies $(\mathrm{p}=0,000)$. Pasangan formula yang memberi pengaruh signifikan adalah cookies F0 dan F1, F0 dan F3, F1 dan F2, sedangkan pada F0 dan F2, F1 dan F3, serta F2 dan F3 tidak memberikan pengaruh warna yang signifikan.

Formula F2 memiliki warna yang bagus, tidak terlalu pucat dan juga tidak terlalu hijau. Warna hijau pada cookies ini dipengaruhi oleh adanya tepung daun kelor yang memiliki warna hijau karena mengandung zat hijau daun yaitu klorofil (Krisnadi, 2012). Selain itu cookies juga memiliki warna yang sedikit kecoklatan yang terjadi karena adanya reaksi maillard. Reaksi maillard ini terbentuk karena adanya penambahan tepung kecambah kedelai yang pada dasarnya mengandung asam amino lisin. Asam amino lisin terbentuk dari dua gugus amin yang bersifat reaktif terhadap gula pereduksi sehingga menimbulkan warna coklat

Tabel 2. Distribusi Tingkat Kesukaan Panelis terhadap Warna Cookies

\begin{tabular}{|c|c|c|c|c|c|c|c|c|c|c|c|}
\hline \multirow{2}{*}{ Formula } & \multicolumn{2}{|c|}{$\begin{array}{c}\text { Sangat Tidak } \\
\text { Suka }\end{array}$} & \multicolumn{2}{|c|}{ Tidak Suka } & \multicolumn{2}{|c|}{ Suka } & \multicolumn{2}{|c|}{ Sangat Suka } & \multicolumn{2}{|c|}{ Total } & \multirow{2}{*}{ Modus } \\
\hline & $\mathrm{n}$ & $\%$ & $\mathrm{n}$ & $\%$ & $\mathrm{n}$ & $\%$ & $\mathrm{n}$ & $\%$ & $\mathrm{~N}$ & $\%$ & \\
\hline F0 & 0 & 0,0 & 2 & 6,7 & 13 & 43,3 & 15 & 50,0 & 30 & 100 & $3^{\mathrm{a}}$ \\
\hline $\mathrm{F} 1$ & 0 & 0,0 & 6 & 20,0 & 24 & 80,0 & 0 & 0,0 & 30 & 100 & $3^{b}$ \\
\hline $\mathrm{F} 2$ & 0 & 0,0 & 3 & 10,0 & 19 & 63,3 & 8 & 26,7 & 30 & 100 & $3^{\mathrm{a}}$ \\
\hline F3 & 0 & 0,0 & 7 & 23,3 & 19 & 63,3 & 4 & 13,3 & 30 & 100 & $3^{\text {ba }}$ \\
\hline
\end{tabular}

Notasi huruf (a,b,ba) yang berbeda menunjukkan adanya perbedaan yang signifikan $(\alpha \leq 0,05)$ 
pada cookies (Avianty dan Ayustaningwarno, 2013).

Penilaian daya terima panelis terhadap aroma cookies yang disajikan pada Tabel 3 menunjukkan bahwa semakin banyak substitusi tepung daun kelor dan tepung kecambah kedelai maka semakin rendah pula tingkat kesukaan panelis. Hasil uji Kruskal Wallis menunjukkan bahwa terdapat pengaruh yang signifikan pada substitusi tepung daun kelor dan tepung kecambah kedelai terhadap aroma cookies $(p=0,000)$. Uji statistik Mann Whitney menunjukkan bahwa substitusi tepung daun kelor dan tepung kecambah kedelai memberi pengaruh signifikan terhadap cookies F0 dan F1, F0 dan F2, F0 dan F3.

Hal ini terjadi karena adanya substitusi tepung daun kelor dan tepung kecambah kedelai yang pada dasarnya memiliki aroma langu. Aroma langu tepung daun kelor ada karena di dalamnya terdapat enzim lipoksidase yang merupakan kelompok heksal 7 dan heksanol (Rosyida, 2016).

Pada kedelai juga terdapat senyawa off flavor, yaitu enzim lipoksigenase. Enzim tersebut mampu menghidrolisis polyunsaturated fat (asam lemak tak jenuh ganda) sehingga menghasilkan senyawa volatil penyebab aroma langu (Endrasari dan Nugraheni 2012).

Pada umumnya, tekstur cookies adalah renyah dan tidak keras. Baik buruknya tekstur makanan dipengaruhi oleh kadar air, kandungan lemak, protein, dan jumlah serta jenis karbohidratnya. Hasil uji daya terima terhadap tekstur cookies yang disajikan pada Tabel 4 menunjukkan bahwa formula F2 memiliki persentase tertinggi kategori suka (96,7\%). Hasil uji Kruskal Wallis menunjukkan bahwa terdapat pengaruh yang signifikan substitusi tepung daun kelor dan tepung kecambah kedelai terhadap tekstur cookies $(\mathrm{p}=0,000)$. Berdasarkan analisis statistik Mann Whitney, formula yang memiliki pengaruh yang signifikan adalah cookies F0 dan F1, F0 dan F2, F0 dan F3, F1 dan F3.

Perbedaan proporsi tepung daun kelor dan tepung kecambah kedelai menjadikan panelis memiliki tingkat kesukaan terhadap tekstur yang berbeda pula. Semakin banyak penambahan tepung daun kelor dan tepung kecambah menjadikan cookies semakin keras, hal ini terjadi karena kedua tepung tersebut mengandung protein yang cukup tinggi, sedangkan untuk membuat cookies

Tabel 3. Distribusi Tingkat Kesukaan Panelis terhadap Aroma Cookies

\begin{tabular}{|c|c|c|c|c|c|c|c|c|c|c|c|}
\hline \multirow{2}{*}{ Formula } & \multicolumn{2}{|c|}{$\begin{array}{c}\text { Sangat Tidak } \\
\text { Suka }\end{array}$} & \multicolumn{2}{|c|}{ Tidak Suka } & \multicolumn{2}{|c|}{ Suka } & \multicolumn{2}{|c|}{ Sangat Suka } & \multicolumn{2}{|c|}{ Total } & \multirow{2}{*}{ Modus } \\
\hline & $\mathbf{n}$ & $\%$ & $\mathbf{n}$ & $\%$ & n & $\%$ & $\mathrm{n}$ & $\%$ & $\mathbf{N}$ & $\%$ & \\
\hline F0 & 0 & 0,0 & 0 & 0,0 & 14 & 46,7 & 16 & 53,3 & 30 & 100 & $4^{a}$ \\
\hline $\mathrm{F} 1$ & 0 & 0,0 & 0 & 0,0 & 26 & 86,7 & 4 & 13,3 & 30 & 100 & $3^{\mathrm{b}}$ \\
\hline $\mathrm{F} 2$ & 0 & 0,0 & 0 & 0,0 & 27 & 90,0 & 3 & 10,0 & 30 & 100 & $3^{\mathrm{b}}$ \\
\hline F3 & 0 & 0,0 & 0 & 0,0 & 29 & 96,7 & 1 & 3,3 & 30 & 100 & $3^{\mathrm{b}}$ \\
\hline
\end{tabular}

Notasi huruf (a,b) yang berbeda menunjukkan adanya perbedaan yang signifikan $(\alpha \leq 0,05)$

Tabel 4. Distribusi Tingkat Kesukaan Panelis terhadap Tekstur Cookies

\begin{tabular}{|c|c|c|c|c|c|c|c|c|c|c|c|}
\hline \multirow{2}{*}{ Formula } & \multicolumn{2}{|c|}{$\begin{array}{c}\text { Sangat Tidak } \\
\text { Suka }\end{array}$} & \multicolumn{2}{|c|}{ Tidak Suka } & \multicolumn{2}{|c|}{ Suka } & \multicolumn{2}{|c|}{ Sangat Suka } & \multicolumn{2}{|c|}{ Total } & \multirow[t]{2}{*}{ Modus } \\
\hline & $\mathrm{n}$ & $\%$ & $\mathrm{n}$ & $\%$ & $\mathrm{n}$ & $\%$ & $\mathrm{n}$ & $\%$ & $\mathrm{~N}$ & $\%$ & \\
\hline F0 & 0 & 0,0 & 0 & 0,0 & 8 & 26,7 & 22 & 73,3 & 30 & 100 & $4^{\mathrm{a}}$ \\
\hline $\mathrm{F} 1$ & 0 & 0,0 & 0 & 0,0 & 28 & 93,3 & 2 & 6,7 & 30 & 100 & $3^{\mathrm{b}}$ \\
\hline $\mathrm{F} 2$ & 0 & 0,0 & 1 & 3,3 & 29 & 96,7 & 0 & 0,0 & 30 & 100 & $3^{b}$ \\
\hline F3 & 0 & 00,0 & 3 & 10,0 & 27 & 90,0 & 0 & 0,0 & 30 & 100 & $3^{\mathrm{b}}$ \\
\hline
\end{tabular}

Notasi huruf (a,b) yang berbeda menunjukkan adanya perbedaan yang signifikan $(\alpha \leq 0,05)$ 
yang digunakan adalah tepung rendah protein agar tekstur yang dihasilkan lebih renyah (Rudianto, 2014).

Rasa yang dihasilkan oleh cookies ini dipengaruhi oleh adanya tepung daun kelor, tepung kecambah kedelai, mentega, gula, dan susu. Hasil penilaian daya terima terhadap rasa cookies disajikan pada Tabel 5 dengan kesimpulan bahwa semakin tinggi proporsi tepung daun kelor dan tepung kecambah kedelai maka panelis semakin tidak menyukai rasa cookies.

Hasil uji Kruskal Walis menunjukkan bahwa terdapat pengaruh yang signifikan substitusi tepung daun kelor dan tepung kecambah kedelai terhadap rasa cookies $(\mathrm{p}=0,000)$. Berdasarkan analisis statistik Mann Whitney menunjukkan bahwa formula yang memberi pengaruh signifikan adalah cookies F0 dan F1, F0 dan F2, F0 dan F3, F1 dan F3. Hal ini terjadi karena adanya rasa khas yang ditimbulkan oleh daun kelor. Rasa ini muncul karena di dalam daun kelor terdapat tanin yang memberikan dampak rasa sepat dan pahit (Rosyida, 2016). Kedelai juga menimbulkan rasa pahit karena adanya reaksi meillard yang terbentuk karena reaksi hidrolisis asam amino (Kurniawati, 2012). Rasa pahit ini dapat disamarkan dengan adanya penambahan gula pada proses pengolahan cookies.

Penilaian keseluruhan daya terima warna, aroma, tekstur, dan rasa cookies yang disajikan dalam Tabel 6 menunjukkan bahwa persentase rerata tertinggi formula yang paling disukai yaitu formula F1 $(88,3 \%)$. Perhitungan secara empiris dengan menggunakan Tabel Komposisi Pangan Indonesia (TKPI) menunjukkan formula F1 memiliki kandungan protein $8,9 \mathrm{~g} / 100 \mathrm{~g}$ cookies dan zat besi sebesar $2,5 \mathrm{mg} / 100 \mathrm{~g}$ cookies.

Hasil uji laboratorium nilai gizi yaitu protein dan zat besi cookies F1 disajikan dalam Tabel 7.

Tabel 7. Nilai Gizi per 100 gram Cookie Formula Terbaik (F1)

\begin{tabular}{lcc}
\hline \multicolumn{1}{c}{ Zat Gizi } & TKPI & Laboratorium \\
\hline Protein $(\mathrm{g})$ & 8,9 & 9 \\
Zat Besi $(\mathrm{mg})$ & 2,5 & 3,88 \\
\hline
\end{tabular}

Tabel 5. Distribusi Tingkat Kesukaan Panelis terhadap Rasa Cookies

\begin{tabular}{|c|c|c|c|c|c|c|c|c|c|c|c|}
\hline \multirow{2}{*}{ Formula } & \multicolumn{2}{|c|}{$\begin{array}{c}\text { Sangat Tidak } \\
\text { Suka }\end{array}$} & \multicolumn{2}{|c|}{ Tidak Suka } & \multicolumn{2}{|c|}{ Suka } & \multicolumn{2}{|c|}{ Sangat Suka } & \multicolumn{2}{|c|}{ Total } & \multirow{2}{*}{ Modus } \\
\hline & $\mathrm{n}$ & $\%$ & $\mathrm{n}$ & $\%$ & $\mathrm{n}$ & $\%$ & $\mathrm{n}$ & $\%$ & $\mathrm{~N}$ & $\%$ & \\
\hline F0 & 0 & 0,0 & 0 & 0,0 & 12 & 40,0 & 18 & 60,0 & 30 & 100 & $4^{\mathrm{a}}$ \\
\hline F1 & 0 & 0,0 & 0 & 0,0 & 28 & 93,3 & 2 & 6,7 & 30 & 100 & $3^{b}$ \\
\hline $\mathrm{F} 2$ & 0 & 0,0 & 2 & 6,7 & 27 & 90,0 & 1 & 3,3 & 30 & 100 & $3^{\mathrm{b}}$ \\
\hline F3 & 0 & 0,0 & 4 & 13,3 & 26 & 86,7 & 0 & 0,0 & 30 & 100 & $3^{\mathrm{bc}}$ \\
\hline
\end{tabular}

Notasi huruf (a,b,bc) yang berbeda menunjukkan adanya perbedaan yang signifikan $(\alpha \leq 0,05)$

Tabel 6. Penilaian Keseluruhan Daya Terima Cookies

\begin{tabular}{|c|c|c|c|c|c|c|c|c|}
\hline \multirow{3}{*}{ Karakteristik } & \multicolumn{8}{|c|}{ Formula } \\
\hline & \multicolumn{2}{|c|}{ F0 } & \multicolumn{2}{|c|}{ F1 } & \multicolumn{2}{|c|}{ F2 } & \multicolumn{2}{|c|}{ F3 } \\
\hline & $\mathbf{n}$ & $\%$ & $\mathbf{n}$ & $\%$ & $\mathbf{n}$ & $\%$ & n & $\%$ \\
\hline Warna & 13 & 43,3 & 24 & 80,0 & 19 & 63,3 & 19 & 63,3 \\
\hline Aroma & 14 & 46,7 & 26 & 86,7 & 27 & 90,0 & 29 & 96,7 \\
\hline Tekstur & 8 & 26,7 & 28 & 93,3 & 29 & 96,7 & 27 & 90,0 \\
\hline Rasa & 12 & 40,0 & 28 & 93,3 & 27 & 90,0 & 26 & 86,7 \\
\hline Keseluruhan & 11,8 & 39,2 & 26,5 & 88,3 & 25,5 & 85,0 & 25,3 & 84,2 \\
\hline
\end{tabular}


Tabel 8. Persentase Nilai Energi dan Zat Gizi Cookies terhadap AKG dan PMT Pemulihan Balita KEP Fase Rehabilitasi

\begin{tabular}{cccccc}
\hline Zat Gizi & Zat Gizi per 100g & AKG* & $\begin{array}{c}\text { Konstribusi } \\
\text { Terhadap AKG } \\
\mathbf{( \% )}\end{array}$ & $\begin{array}{c}\text { PMT ** } \\
\text { Pemulihan }\end{array}$ & $\begin{array}{c}\text { Konstribusi } \\
\text { Terhadap PMT } \\
\text { Pemulihan (\%) }\end{array}$ \\
\hline Protein $(\mathrm{g})$ & 9 & 26 & 34,6 & 8,7 & 103,4 \\
Zat Besi $(\mathrm{mg})$ & 3,88 & 8 & 48,5 & 2,7 & 143,7 \\
\hline
\end{tabular}

Sumber:

* = Angka Kecukupan Gizi 2013

**= Direktorat Bina Gizi (2012)

Terdapat peningkatan kadar protein dan zat besi setelah dilakukan uji laboratorium. Kadar protein dan zat besi ini telah memenuhi standar PMT balita KEP fase rehabilitasi yaitu $103,4 \%$ dan $143,7 \%$.

Protein dalam kadar yang tinggi sangat diperlukan bagi balita KEP fase rehabilitasi untuk tumbuh kejar. Protein yang terdapat dalam kecambah kedelai memiliki bentuk yang lebih sederhana bila dibandingkan dengan kedelai, sehingga lebih mudah dicerna oleh balita KEP fase rehabilitasi (Nwamaka, 2008).

Zat besi dalam cookies tepung daun kelor dan tepung kecambah kedelai sangat baik untuk tumbuh kejar balita KEP fase rehabilitasi. Daun kelor juga memiliki kadar zat besi yang tinggi. Zat besi perlu untuk mengatasi anemia yang sering terjadi pada balita KEP (Andriani dan Wirjatmadi 2013). Menurut WHO, anemia yang terjadi pada balita akan mengganggu perkembangan dan pertumbuhan serta menjadikan balita mempunyai daya tahan tubuh yang rendah terhadap infeksi, maka dari itu konsumsi zat besi dalam jumlah yang cukup sangat penting untuk memperbaiki kondisi KEP.

\section{KESIMPULAN DAN SARAN}

Hasil uji daya terima karakteristik warna, aroma, tekstur dan rasa secara keseluruhan tertinggi adalah F1 (substitusi tepung daun kelor $10 \mathrm{~g}$ dan tepung kecambah kedelai $40 \mathrm{~g}$ ). Kadar protein dan zat besi cookies F1 per 100g secara berturut-turut adalah $9 \mathrm{~g}$ dan 3,88 mg. Protein dan zat besi telah memenuhi 103,4\% dan 143,7\% standar PMT.

Formula F1 berpotensi dijadikan sebagai alternatif PMT pemulihan balita KEP fase rehabilitasi. Saran penyajian dapat diberikan 2 kali dalam sehari dengan porsi $50 \mathrm{~g}$ ( 2 keping) sekali makan.

\section{DAFTAR PUSTAKA}

Adriani, M., \& Wirjatmadi, B. (2012). Pengantar gizi masyarakat. Jakarta: Kencana Predana Media Group.

Avianty, S., Ayustaningwarno, F. (2013). Kandungan zat gizi dan tingkat kesukaan snack bar ubi jalar dan kedelai hitam sebagai alternatif makanan selingan penderita diabetes melitus tipe 2 . Journal of Nutrition College, 2(4), 622-629.

Endrasari, R., \& Nugraheni, D. (2012). Pengaruh berbagai pengolahan sari kedelai terhadap penerimaan organoleptik. Prosiding Seminar Nasional Optimalisasi Pekarangan, Semarang. Diakses dari jateng.litbang.pertanian.go.id/

Harisina, A.A. (2016). Mutu organoleptik, nilai gizi (protein, kalsium, serat) dan nilai ekonomi flakes substitusi buah sukun dan kacang hijau sebagai alternatif PMT anak sekolah (Skripsi tidak diterbitkan). Universitas Airlangga, Surabaya.

Kementerian Kesehatan RI. (2011). Bagan tatalaksana anak gizi buruk: Buku I. Jakarta: Direktorat Bina Gizi.

Krisnadi, A.D. (2012). Kelor super nutrisi. Diakses dari http://Kelorina.Com

Kurniawati, A.F. (2012). Pengaruh substitusi tepung terigu dengan tepung tempe dan tepung ubi jalar kuning terhadap kadar protein, kadar $\beta$-karoten, dan mutu organoleptik roti manis. Journal of Nutrition College, 1(1), 344-351.

Nursanyoto, H. (2012). Nutrisi anti penuaan dini. Jakarta: Mulia Medika.

Nwamaka, N.O. (2008). Yogurt fortification with predigested/germinated whole soybean powder for enhanced therapeutic benefits (Doctor's thesis, Michigan State University, USA). 
Diakses dari www.intfoodtechno2010.org/ includes/data/2F1.pdf

Rosyidah, A.Z. (2016). Studi tentang tingkat kesukaan responden terhadap penganekaragaman lauk pauk dari daun kelor (Moringa oleivera). E-journal Boga, 5(1), 17-22.

Rudianto. (2014). Studi pembuatan dan analisis zat gizi pada produk biskuit moringa oleifera dengan substitusi tepung daun kelor (Tesis). Universitas Hasanudin, Makassar.

WHO. (2014). Global and regional trends by WHO regions, 1990-2014 Underweight. Diakses dari http://apps. who.int/gho/data/view.main. NUTWHOUNDERWEIGHTv. 